\title{
3. SEDEFASTI ODSJEV VJEČNOSTI. TANATOLOŠKI ASPEKTI KNJIŽEVNOG DJELA VLADANA DESNICE
}

\section{Vladan Bajčeta}

UDK: 821.163.42Desnica, V.:129

Izvorni znanstveni članak

Sažetak: Viziju smrti u opusu Vladana Desnice nije moguće svesti na jednoznačno kritičko određenje. Desničina književna tanatologija pretpostavlja izrazitu raznolikost u prikazivanju i poimanju čovjekove egzistencijalne konačnosti. U rasponu između metafizičkog optimizma sa jedne i pesimizma sa druge strane, Desničini književni tekstovi pokrivaju najšire područje. Rad ispituje odnos Desničinih tanatoloških varijacija u različitim modusima njegovog književnog izraza i pokušava da odgovori na pitanje kako razumjeti predstavu smrti kod pisca koji je u svojim tekstovima na najraznovrsnije načine literarno oblikuje. ${ }^{1}$

Ključne riječi: smrt, umiranje, pogreb, vječnost, sedef, apokaliptično, non omnis moriar

\section{UvoD}

agledan u perspektivi naznačenoj naslovom rada, književni opus Vladana Desnice ukazuje se u svijetlu dvije važne pretpostavke: prva je da smrt predstavlja njegovu tematsko-motivsku dominantu, a druga da je taj fenomen u njemu umjetnički preispitan iz nekoliko nesaglasnih, nerijetko oprečnih uglova. Posmatrajući ga u kontekstualnoj ravni, Desničino djelo upoređeno, s jedne strane, sa djelom Borisava Stankovića i Ive Andrića, a s druge, sa stvaralaštvom Miloša Crnjanskog, otkriva, uz izvjesnu generalizaciju, da je, u odnosu na pomenute pisce, smrt kod Desnice prikazana u daleko većoj smisaonoj heteronomnosti. Naime, dok je u Andrićevom i Stankovićevom književnom svijetu smrt dominantno poimana sa naglašeno tragičnim predosjećanjem, a kod Crnjanskog u slutnji postojanja jedne onostrane, kako je to kritika označila, „povlašćene“ sfere, ${ }^{2}$ kod Desnice je vidna misaona kolebljivost povodom smrti u svakom pojedinačnom domenu njegovog

$\overline{1}$ Rad je nastao u okviru projekta Kulturološke književne teorije i srpska književna kritika (178013), koji finansira Ministarstvo prosvete, nauke i tehnološkog razvoja Republike Srbije.

2 Петар ЏАџит, Повлашћени простори Милоша Црнанског, БеограА 1993. 
umjetničkog ispoljavanja. Ta specifična razlika sama po sebi ne predstavlja afirmativni kvalitativni predznak u smislu Desničine prednosti u odnosu na pomenute autore, niti, pak, u pogledu „filozofske“ inkoherentnosti njegovoga opusa. Međutim, u toj distinkciji otkriva se jedno važno obilježje - Desnica je, pridajući, bilo implicitno bilo u vidu eksplicitnih refleksija, krajnje suprotstavljena značenja odgovoru na pitanje čovjekove smrtnosti, taj prostor umnih napora podredio estetskim zakonima književnog stvaranja. Shvatanje smrti je u svakom Desničinom radu funkcionalizovano u datom kontekstu, i njegov smisao uvijek je time determinisan. Ukoliko bi se, ipak, fenomen smrti posmatrao izdvojeno, onakvim kakvim ga Desnica iznova umjetnički propituje, različitost njegovih imanentnih „zaključaka“ mogla bi biti shvaćena i kao pokušaj da razmatranje metafizičkih nijansi (ta riječ pokazaće se prikladnijom nego što na prvi pogled izgleda), uzetih u rasponu njihovih najudaljenijih krajnosti, pronađe izlaz u određenom smjeru. Stoga jedno hronološki zasnovano istraživanje tanatoloških aspekata Desničinog književnog djela vodi potencijalnoj hermeneutičkoj produktivnosti, utoliko što piščev umjetnički odnos prema smrti ne isključuje lični pogled na svijet, u njegovoj podrazumijevanoj podložnosti permanentnoj promjeni.

\section{OZBILJNO-SMIJEŠNA SMRT - ZIMSKO LJETOVANJE}

Opštepoznato i razložno prihvaćeno kritičko stanovište o Zimskom ljetovanju kao romanu susreta dvaju kulturnih paradigmi, o umjetničkoj viziji nesvakidašnje civilizacijske disparatnosti geografski susjednih svijetova, pronalazi u temi smrti svoju konačnu potvrdu, ujedno i tačku nove analitičke provjere. ${ }^{3} \mathrm{U}$ pripovijednom mizanscenu toga romana smrt predstavlja motivsku dominantu oko koje pisac oblikuje svoju umjetničku zamisao. Desnica razvija jedno, za tada aktuelni književnoistorijski kontekst apartno viđenje smrti, varirajući ga u ozbiljno-smiješnom registru sve do konačne, najdubljim tragizmom prožete vizije. Pretežno realističko-naturalistički prosede sa izraženom komičkom crtom označava upravo taj, u poetičkom smislu prevratnički karakter Zimskog ljetovanja. Međutim, pisac se nije zadržao na nivou makar i superiorne literarne igre, već je na djelu očigledno stvaralački promišljena i skrupulozna realizacija plana čiji je ishod estetsko-antropološka objektivizacija konkretnog istorijskog iskustva smještenog u sjevernodalmatinski ratni hronotop.

Umjetnička uspjelost Desničinog prvog romana umnogome duguje odmjerenoj primjeni grotesknih, humornih, karikaturalnih i drugih elemenata iz komičkog repertoara, koji do stravičnog epiloga vode nepouzdanim putem drastičnog iznevjeravanja čitaočevog horizonta očekivanja. Naime, učestalost i kolektivnost umiranja u opisanom svijetu doprinijela je izvjesnoj devalvaciji smrti, u čemu je pisac prepoznao i iskoristio postojeći smjehovni potencijal. Čovjekovu paralisanost pred iznenadnim i sveopštim stradanjem, koja je u njemu pokrenula psihološki mehanizam poricanja, Desnica prikazuje u groteskno-komičnoj sceni prvog susreta preživjelih u romanu Zimsko ljetovanje:

Klasifikacija i opis identitetâ položenih u osnovi date opozicije precizno su sprovedeni u studiji: Davor Dukić, „Nekoliko imagoloških opaski o Zimskom ljetovanju i Desničinim susretima“, Desničini susreti 2005. - 2008. Zbornik radova (ur. Drago Roksandić i Ivana Cvijović Javorina), Zagreb 2010., 149-156. 
Iz puste uličice ispadne preda njih čudna spodoba čovjeka - na prvi mah ne prepoznaše je li muško ili žensko: lice mu je potpuno pepeljasto, naježena kosa strši mu na glavi, prosjeda od pepela i prašine; izbečio oči kao tenac i ide uličicom s osjećanjem živa zakopana, pogotovo $s$ nevjericom da je zbilja živ i da vidi žive ljude. Upućuje se prema njima, hoće mu se da se osjeti među svojima, među živima, da oćuti njihovu toplinu. Ali u njima pobuđuje ludi strah i nagon da bježe, s prastarom panikom s kojom su ljudi bježali od gubavaca. Nepoznati krene ravno na Ernesta, koji je bio zaostao: da mu je samo malo bliže prišao ili pružio ruku da ga dohvati, Ernesto bi bio dreknuo. On požuri i probije se usred gomile. ${ }^{4}$

Ovaj pasus predstavlja značajnu tačku u motivacijskom sistemu romana, budući da, osim što prološkom pozicijom inicira tretman teme u spektru ozbiljno-smiješnog, smisaono korespondira sa prvim pojavljivanjem građana u Smiljevcima:

U selo banuše u sam sumrak, bijeli od prašine i mrtvi umorni. Seljani su ih gledali u slutnji, raskolačenih očiju, kao ljude koji dolaze sa drugog svijeta. ${ }^{5}$

Mada nisu iskusili haos masakra sa ulica razrušenog Zadra, seljani, kako pripovjedač sugeriše, došljake posmatraju „u slutnji“ onog što se zbilo, i njhova reakcija podudarna je sa prizorom iz prethodnog navoda. I „čudna spodoba“ i grupa gradskih izbjeglica u knjizi su predočeni kao povratnici „sa drugog svijeta“, čime apokaliptički strah od smrti, koji je rat donio među likove romana, prvi put građane i seljane izjednačava pred licem sablasno izmijenjene stvarnosti.

Jedno od središnjih mjesta (u kompozicionom smislu) u Zimskom ljetovanju zauzima opis smrti popadije Darinke: XVIII, XIX i XX poglavlje posvećeni su pripremama za sahranu i sam ukop, pri čemu se pripovjedač, prema već razvijenoj praksi sučeljavanja oprečnih kulturnih perspektiva, fokusira na razlike u pogrebnim običajima gradskih i seoskih sprovoda. Svojevrsni povratak u „svakodnevnost“ od rata „nezavisne“ smrti, označio je i nov pristup temi. Smijeh se sada ne pojavljuje u tragovima pripovijedne stilizacije, već komika postaje njenim supstancijalnim određenjem:

Građanke umuknu slušajući naricaljke seoskih žena. Anita se zamisli. Da, nekad se i u tome znao red. Nisu to bila baš stroga pravila, ali postojao je neki osjećaj - nešto kao ukus - koji je u tom rukovodio, jednako kao i u njenom krojačkom zanatu, i kazivao što odgovara a što ne odgovara, što kome pristaje a što ne pristaje. I po tom osjećaju, po tom ukusu, čovjek je nepogrešivo pogađao pravu mjeru, osjećao na vlas svaku nijansu... Da, znalo se nekad!... Po tim nepisanim pravilima koja je diktirao ukus a koja su važila u njene dane, ridalo se samo za bračnim drugom, ako je brak mlađi od godine dana, ili najviše do 18 mjeseci, i za vjerenikom, ako su postojale formalne zaruke; iznimno, i bez formalnih zaruka, među umjetnički taknutim svijetom (kad je zaručnik nosio dugu kosu i kravatu la v a ll i é r e; u tom je slučaju čak vjerenica mogla koračati za sprovodom sa raspletenom kosom). Za vjerenikom ili suprugom sa štucanim brcima, kosom podšišanom „četkasto“ i sa očalima na štipaliku - za čovjekom od energična izgleda i od aktentaše - ni u kom slučaju nije se ridalo, nego jednostavno plakalo; a ako je prešao 55 godina, eventualno i samo suzilo. Isto tako suzilo se za zetom, za dobrim poslodavcem kod koga smo u službi dulje od 3 godine, za mužem najbolje prijateljice (naravno, ako nije bivao grub prema njoj), te eventualno za svakim dobrim čovjekom koji za sobom ostavlja troje ili više djece. Sto se tiče jecanja, jecanje

4 Vladan Desnica, Zimsko ljetovanje, Sarajevo 1966., 18.

5 Isto, 30. Podvukao V. B. 
uopće nije stil (i zato, kad neko počne da kontinuirano jeca, prekinu ga kao čovjeka koji je krivo zapjevao). Jecaj se upotrebljava pojedinačno, kao p i z z i c a t o, na tačno određenim mjestima: kad Pop intonira nazalno „r e q u i e m a e t e r n a m..."; kad se začuju prvi kucaji čekića koji prikucavaju poklopac lijesa; u času kad četiri crna čovjeka (s onim groznim crnim epoletama s resama!) dignu lijes sa poda; ili kad lijes - crn, uglat, naoko nepokretan zalebdi skoro bez težine na užetima u zraku nad otvorenom rakom, kao da plutâ. I možda još u dva do tri takva slučaja. ${ }^{6}$

Očito je kako pisac na nekoliko nivoa humorno razobličuje Anitino viđenje naricanja seoskih žena: građanske konvencije suprotstavljene seljačkom rutinerstvu komične su u ozbiljnosti kojom junakinja katalogizuje bizarne kriterijume za „ridanje“ prema onome što imenuje „nešto kao ukus“. Na drugom stupnju, za šta navedeni pasus daje uzoran primjer u romanu obilato primjenjivane tehnike, uočava se kako Desničin pripovjedač svoj glas upliće u frazeološko-psihološku tačku gledišta kojom je tekst u datom trenutku posredovan, i na ovom mjestu razvija poređenje ,jecanja“ sa specifičnom tehnikom muziciranja („pizzicato “), efektno karikirajući posmrtni protokol građana u njegovoj operetskoj izvještačenosti. Čitava epizoda dovedena je do crnohumornog paroksizma u završnoj sceni, kada Petrina silazi u raku da bi u sanduk (,između dvije letve [...] kao u poštansko sadnuče“) ${ }^{8}$ ubacio pismo iz šibenske ludnice, kojim pokojnicu „posthumno“ obavještava o pogibiji njenog sumasišavšeg sina tokom posljednjeg „bombardmana“. Desnica je, očigledno sa punom autorskom sviješću, od početka prema sredini romana smrt prikazivao gradacijski, u pravcu ozbiljnog ka smiješnom, da bi sliku umiranja ka završetku poveo u sasvim suprotnom smjeru.

Prizor smrti bebe Špižmice predstavlja kulminatornu tačku romana. Pažnju prije svega treba obratiti na nagovještaje kojima je Desnica diskretno sugerisao epilog radnje. Jedna vrsta umjetničke elegancije odlikuje piščeve simboličke anticipacije, budući da je njihov metasemantički karakter neupadljivo pridodat osnovnom značenjskom nivou teksta. Prvi opis dječje smrti u trećem poglavlju, karakteristično bezosjećajan - saobrazno načinu na koji su prikazane i ostale žrtve bombardovanja („vise tako dječja tjelešca, presumićena preko žica kao djetinje haljinice izvješane na sušenje“) $)^{9}$ - kritika je već dovela u vezu sa završnom scenom. ${ }^{10}$ Međutim, dosadašnja tumačenja propustila su Desničinu suptilnu simbolizaciju zooloških motiva, koja analizu neminovno usmjerava u sasvim određenom pravcu. Već na samom početku romana narator signalizira čitaocu:

6 Isto, 105-106.

7 Izrazito subjektivno obojen glas pripovjedača Zimskog ljetovanja kritika je istakla u više navrata: „Ovu knjigu s ironičnim oksimoronom kao naslovom, ne možemo nazvati romanom u pravom smislu riječi, jer umjesto radnje, zapleta i raspleta, sadrži eruditivno pričanje autora, koji ne krije svoju intelektualnu nadmoćnost i gotovo nezainteresiranost za temu o kojoj izvješćuje“" Vlatko Pavletić, Analiza bez koje se ne može, Zagreb 1961., 247. „Zanimljivo je da im se u eksploataciji toga tematskog horizonta rado priključuje i pripovjedač, u čijem se 'sveznajućem' diskursu likovi i njihove sudbine uglavnom i uspostavljaju, jer je Zimsko ljetovanje pretežno pripovjedački roman, s razmjerno malo dijaloških partija." Zoran Kravar, "Zimsko ljetovanje Vladana Desnice pod ideološkokritičkim lećama“, Desničini susreti 2010. Zbornik radova (ur. Drago Roksandić i Ivana Cvijović Javorina), Zagreb 2011., 10.

8 V. Desnica, Zimsko ljetovanje, 111.

Isto, 19.

10 „Neotklonjiva brutalnost ove deskripcije, stilski, ali ne i značenjski ublažena tek završnim poređenjem, objašnjiva je, možda, tek iz perspektive završnice celog romana, koja i sama prikazuje brutalnu, iako - makar na prvi pogled - kulturološki oprečnu scenu detinjeg stradanja, ne u strci bombardmana, nego u čeljustima životinje." Тихомир Брајовић, „Облик празнине. Културни идентитети и њихова наличја у Зимском љетовағу Владана Аеснице“, 
Ali selo ima jednu naročito ružnu stranu: to su zmije! Ima ih sva sila; svagdje i na svakom mjestu; stvore se čudom, kao iz ničega. One se odgone vonjem zapaljene krpe. Podmukle su, kao i njihovi gospodari seljaci (koje ujedaju mnogo rjeđe i mnogo manje rado nego građane); ima ih i takvih koje strelovitom brzinom jure za čeljadetom sikćući jezivo, pri čemu taj fijuk raste u tonu uporedo s brzinom zmijina kretanja, od čega se jadnom bjeguncu noge ukoče a srce skoči u grlo te ne može dalje ni makac. (Jednom je jedna majka našla smotanu zmiju pod uzglavljem svog djeteta. $)^{11}$

Odlomak svojim prvim stepenom značenja pripada onom sloju romana koji konstituiše ukrštanje suprotstavljenih imagoloških perspektiva. Međutim, njegov povlašćeni položaj u prvom poglavlju, kao i činjenica da je fokalizovan u optici Špižmicine majke Lizete, značajno doprinosi metaforičkoj čitljivosti posljednje rečenice (dodatno istaknute zagradom) u smislu tradicionalne simbolizacije smrti. Tom malom, usputnom napomenom da je majka pronašla smotanu zmiju pod uzglavljem svog djeteta Lizetina kobna pomisao na delikatan način najavljuje ishod izbjegličkog boravka u selu. Ovakvo razumijevanje uporište pronalazi i u drugim Desničinim tekstovima. Naime, u LXI poglavlju Proljeća Ivana Galeba, kada se glavni junak prisjeća smrti svoje kćerke, on njenu nasljednu porodičnu bolest metaforički imenuje riječima: „Pitoma zmija pokućarka“. ${ }^{2}$ Sličan motiv pronalazi se i u pojedinim Desničinim pjesmama. ${ }^{13} \mathrm{Zmija}$ predstavlja uobičajenu simboličku oznaku smrti u Desničinoj umjetnosti, pa tako i u Zimskom ljetovanju.

Piščeva narativna signalizacija istančano se razvija u IX poglavlju, u cjelosti posvećenom prascu Migudu. ${ }^{14}$ Migud uživa poseban tretman u zajednici kojoj pripada; kaže se, sa upadljivo humornom intonacijom, da je Migud „glavna ličnost u Ićanovom kućanstvu“. 15 Njegova privilegovanost istaknuta je i vlastitim imenom koje se obično ne daje svinjama; a „monumentalna“ pojava pripovjedački je upadljivo prokomentarisana: „izgledao je ne pojedinačni, živ krmak, nego sam spomenik svinjskom rodu“. ${ }^{16}$ Višestruko je, dakle, indicirana važnost uloge koju Migud posjeduje. Međutim, jednom marginalnom opaskom, prikrivenom u usputnosti poređenja, pripovjedač Miguda uvezuje u simbolički sistem teksta. Ićanov povratak sa sajma, na kome je kupio svog mezimca, upečatljiv je u pogledu stila:

Vozi se Ićan između njiva, pod zvijezdama; zagrnuo se crnim suknenim haljkom preko glave, klati se pijano na sjedištu i bugari nekakav napjev bez kraja i konca koji se nejasno izvija kroz grubo sukno haljka, a za njim cijuče kolo oko izlizane osovine i ocrtava u prašini zmijast trag. ${ }^{17}$

Књижевно дело Владана Аеснице. Зборникрадова поводом 100-годишњице рођења (ur. Јован Радуловић, Аушан Иванић), Београд 2007., 106.

11 V. Desnica, Zimsko ljetovanje, 8-9.

12 Владан АЕсницА, Прољећа Ивана Галеба, Београд 1990., 304.

13 Vladan DesnicA, „Začarano popodne“, Slijepac na žalu, Zagreb 1956., 9.

14 Zapažen privilegovani status ovog „junaka“ knjige potvrđuje stav o Zimskom ljetovanju kao romanu u tradiciji ozbiljno-smiješne književnosti: „Štoviše, ne može se zaboraviti da u ovom romanu jedan od aktera jeste čak jedan krmak, Migud, koji je jedini sa pravom - takoreći - biografskom karakterizacijom (poglavlje IX), što označava i ironijsku notu pripovjedača, i tragičnu grotesknost prikazane stvarnosti, i spomenutu problematizaciju figure protagonista.“ Luca VAGLIO, „Vidovi policentrizma i problematičnosti u romanu Zimsko ljetovanje Vladana Desnice“, Desničini susreti 2010. Zbornik radova (ur. Drago Roksandić i Ivana Cvijović Javorina), Zagreb 2011., 104.

15 V. DesnicA, Zimsko ljetovanje, 50.

16 Isto.

17 Isto, 51. Podvukao V. B. 
Desnica je, kako se vidi, prefinjen vodič svom čitaocu: Migud u selo dolazi putem po kojem ostaje „zmijast trag“, kao u nekakvom stravičnom ovaploćenju, ili metamorfozi Lizetine mračne slutnje sa početka romana. $\mathrm{Na}$ taj način jedan tradicionalni životinjski simbol smijenjen je novim, umjetnički individualizovanim, sa namjerom da se neselektivnost nasilne smrti proizvedene civilizacijskim posrnućem Drugog svjetskog rata u svojoj strahotnosti izjednači sa smrću u praiskonskom, prirodnom okruženju. Tu se zaokružuje misaoni obzor romana: selo i grad pred smrću gube svoje razlike, a Migud je samo jedna od njenih mogućnosti, podjednako surova kao i ona kojoj su junaci romana privremeno umakli. To je razlog zbog koga Desnica dosljedno održava ravnomjernu ekspresivnu „bezosjećajnost“ kojom su prikazani i mrtvi građani nakon bombardovanja i Špižmicina stravična smrt. Otuda tema smrti razrješava dualizam Zimskog ljetovanja - sistemi kulture, ili njeni nivoi, suprotstavljeni su sa ciljem da se pred licem opisanih stradanja izbrišu njihove razlike.

\section{NeZnATNOST POJEDINAČNE SMRTI - PRIPOVIJETKE}

U svojim pripovijetkama Desnica će proširiti umjetnički i misaoni opseg vlastitih tanatoloških varijacija. Ukoliko bi se tražio imenitelj pristupu naznačenoj tematici u tome dijelu piščevog opusa, sintagma neznatnost pojedinačne smrti pokrila bi njegovo načelno određenje. ${ }^{18}$ Pretežan broj Desničinih, naročito ranih pripovijedaka, završava smrću glavnih ili sporednih junaka, pri čemu se posredstvom pripovjedačeve koncentracije na trivijalnost úzrokâ njihovog stradanja, kao i na sam proces umiranja, potcrtava sudbinska i ljudska nezainteresovanost: njihov nestanak, uprkos imanentnom i konkretnom tragizmu, prikazan je u atmosferi opšte indiferentnosti. Desničine likove odnosi starost, bolest, samoubistvo, egzekucija, puka slučajnost, ali je svim tim smrtima zajednička ravnodušnost u kojoj se one događaju. To temeljno određenje uslovilo je niz filozofskih, etičkih, antropoloških i drugih pitanja, koja su u većem broju pripovijedaka uzorno umjetnički promišljena. Uzorna je u tom smislu priča Oko iz piščeve prve zbirke Olupine na suncu. ${ }^{19}$

U toj pripovijeci prepoznaje se jedna od Desničinih čestih tematskih preokupacija: kolizija ruralnog i urbanog mentaliteta. Za razliku od Zimskog ljetovanja, žrtva toga sudara sada dolazi iz seoske sredine, mada je veći dio života provela u gradu. To postaje glavnim uzrokom tragedije služavke Kate: neautentična pripadnost bilo kojem od dvaju svijetova proizvela je odbačenost uslovljenu, s jedne strane, Vandinom malograđanskom osvetoljubivošću, a sa druge, primitivnom beskrupuloznošću Bariše i njegovih ukućana. Desnica

18 Ivan Galeb kaže da je u mladalačkom doživljaju smrt poimao kao „znamen neznatnosti ljudske jedinke“. B. АЕсница, Прољећа Ивана Галеба, 81.

19 Sam pisac sažeo je svoju pripovijetku: „Ja bih ukratko njenu temu sažeo ovako: u učmalom, jednoličnom životu jedne sredine, jednog skupa lica - životu koji bi inače tekao tako, bez potresâ i bez znatnijih promjena, sve do smrti - desi se mali, neznatni događaj: dr Lovro okapa pogrešne kapljice u oko nekom pacijentu, i ovaj gotovo oslijepi. Od tog događaja sve se uzmrsi, uznemiri, poremeti, sudbine aktera poteku drugim tokom - i često tokom sasvim protivnim onome koji bi se mogao pretpostaviti: 'slipcu' gubitak oka postaće osnov njegovog blagostanja i značiti početak 'dostojnijeg života'; Lovri će taj događajčić biti prekretnica u njegovom bračnom životu i u njegovom sretnom živovanju uopće; a bijednu Katu koja je u čitavoj toj stvari najmanje zainteresirana i za obje strane najzaslužnija, od tog događaja nit njene sudbe odvesti će - ravno u bunar. - Eto, to je ono što sam htio da ispričam." ВАадан АЕсницА, Есеји, илании, погледи, БеограА - Приштина 1993., 180-181. 
autorskoj eksplikaciji psihološke i etičke degradacije već po sebi dekadentne Vande i lažnog prosperiteta sirotog i sirovog Bariše pretpostavlja pripovjedni prikaz neurotičnog bijega u „nemirni duh novotarija“, u prvom, i skorojevićko šepurenje pribavljenim „ugledom“, $\mathrm{u}$ drugom slučaju. ${ }^{20} \mathrm{U}$ tom smislu posebno su učinkovita Desnici svojstvena lajtmotivska uvezivanja narativnih sekvenci, koja njegove tekstove drže na najvišem stupnju umjetnič-

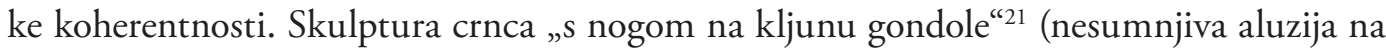
nedostižnu Veneciju iz Vandinih maštanja), koji je dočekivao pacijente u hodniku ispred ordinacije, nošen Vandinom manijom preuređivanja dobija novo mjesto u kući -

dospio je u jedan zabačeniji kutak na sumračno stubište koje je vodilo u vrtić, gdje je bio izložen vlazi tako da su uskoro počele od njega otpadati korice i ljuštiti se sedefasti odsjevi sa čalme. Sad su na kljun njegove gondole naslanjali probijeni lavor sa mekinjama za kokoši. ${ }^{22}$

Kičersko otjelovljenje filistarskog sna o životu u velikom svijetu skončava u jednom kućnom budžaku, kao simbol ćiftinog poraza od strane podlog varvarina. $\mathrm{Na}$ isti način, samo u suprotnom smjeru, semantički je funkcionalizovano poređenje u posljednjoj rečenici pripovijetke, kojim je stilizovan Katin leš na dnu bunara: „slična razapetu kišobranu nadula se mokra oblina Katine suknje“. ${ }^{23}$ Ta stilska figura u svijesti pažljivog čitaoca aktivira jednu raniju scenu: „dr. Pivčević, vragoljan bolnice i maza časnih sestara; stojeći iza leđa Furatu koji se natezao sa podosta otvrdnulom špricom, stade oponašati njegove kretnje otvarajući i zatvarajući kišobran“. ${ }^{24}$ Povezujući, u samoj završnici, posredstvom upečatljive jezičke slike dva prizora, pisac aluzivno poentira ko je prava žrtva Furatove profesionalne nemarnosti. Budući da nòsēći amblemi pripovijetke - skulptura i kišobran - bilo u svojoj materijalnoj pojavnosti bilo u naratorskoj stilizaciji postaju krhotine, dakle olupine ranijih ukrasnih, odnosno upotrebnih predmeta, Desničinom viđenju smrti pojedinca kao neznatnog događaja pribavljaju željeni umjetnički izraz.

Istovrsna „bagatelizacija“ smrti sreće se i u drugim Desničinim pripovijetkama. Florjanović je, prema poetičkoj reprezentativnosti, u tom smislu egzemplaran. Ta pripovijetka, zajedno sa pripovijetkom Oko, kao i još nekim naslovima, poput priča Pred zoru ili Bunarevac, reprezentuje u svojoj značenjskoj pregnantnosti i formalnoj dovršenosti najviši nivo Desničine novelistike. Interesantna je činjenica da sve te pripovijetke pripadaju onoj grupi u koju je sam pisac svrstao svoje „proze (...) pretežno regionalnog vida“, odvajajući ih od pripovijedaka „općenitijeg, sasvim neregionalnog karaktera“, koje, kako je isticao, „predstavljaju njegovu preču preokupaciju“. ${ }^{25}$ Desnica se ogradio od vrednosnog suda („bez obzira na valutacije“) ${ }^{26}$ ali je nesumnjivo da je opšti narativni model prvih - prevlast naracije nad refleksijom, nasuprot naglašenoj diskurzivnosti drugih - pružio više prostora njegovim stvaralačkim mogućnostima. ${ }^{27}$

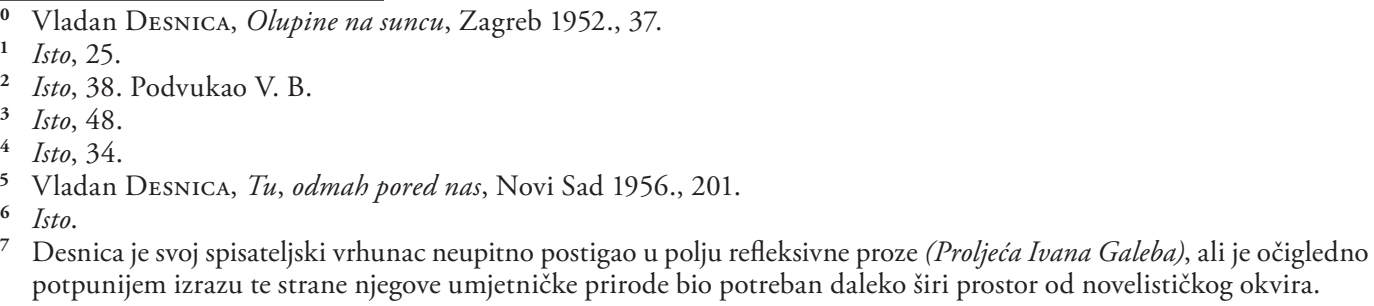
potpunijem izrazu te strane njegove umjetničke prirode bio potreban daleko širi prostor od novelističkog okvira. 
Nasuprot pripovijeci Oko, samoubistvo Celsa Florjanovića ne dolazi kao čin oslobođenja od svekolike ljudske nepravde, već kao bijeg pred zemaljskom pravdom. Pisac svog junaka spasava jednodimenzionalnosti, budući da se Florjanović u izvjesnom smislu žrtvuje za porodicu, i njegov karakter ne podliježe bez izuzetka čitaočevim antipatijama. I tu do izraza dolazi Desničina umjetnička suptilnost kada je riječ o odnosu pojedinosti i cjeline. Uopšte posmatrano, Desničina stilematika rijetko se zadovoljava primarnim, kod osrednjih pisaca i pogrešno shvaćenim zadatkom slikovitosti prikazivanja: njegova poređenja samo u perifernim, digresivnim pasusima mogu ostati na nivou jezičkog artizma sa ulogom stilske dekorativnosti. Njima se češće, sa vidnom autorskom intencijom, pridaje noseći semantički potencijal. U nesumnjivoj važnosti njegove uloge lako uočljiv detalj jeste oružje kojim će Florjanović sebi oduzeti život. Pripovjedač ga opisuje iscrpno, uz primjetno uplitanje junakove svijesti o predmetu:

Bio je to mali revolver poniklovane cijevi i s drškom od sedefa. Izgledao je bezazleno, kao da spada u garnituru s isto tako sedefnim dogledom za teatar i kao da služi samo za to da se iz njega, uz osmijeh i reverans, puca iz lože u ložu, među znancima u fraku i s papirnatim fesom na glavi. ${ }^{28}$

Napuštajući početno komični napor da oduzme svaku ozbiljnost funkciji „te spravice“, Florjanović se zatim prisjeća kada ju je prvi i jedini put upotrebio: bilo je to na povratku sa jednog porodičnog izleta, kada ih je napala „nekakva crna ptičurina“, koja se njegovoj supruzi Dolores učinila "gotovo kao nekim rđavim znamenom“ ${ }^{29}$ Metak je pticu promašio, ali je ona odletjela i izletnici su nastavili put. I tu je opet na djelu Desničino prepoznatljivo nagovještavanje - pogled unatrag osvjetljava jedan deskriptivni pasaž, vezan za trenutak neposredno pošto inspektor Raše otpočinje pregledanje Florjanovićevih sudskih knjiga, a momenat prije nego Florjanović potone u svoje evokacije - pripovjedač tada predočava ambijent u kojem će se pripovijest dalje odvijati:

Napolju se bilo skoro već sasvim smračilo. Ipak, sa visine drugog kata vidjela se u daljini, nad lukobranom, zadnja pruga svijetla na zreniku. Pred otvorenim prozorom prolijetale su kosim strelimičnim letovima lastavice bljeskajući kao sedefne strijele i smještale se sa živim predvečernjim cvrkutom u gnijezdima pod prozorskim podbojem. ${ }^{30}$

Čitalačka svijest koja, u završnici pripovijetke, taj segment teksta drži aktivnim u sjećanju, ostvaruje jednu od njegovih idealnih konkretizacija: njoj se predočava sofisticirana projekcija unutrašnjeg stanja protagoniste u hronotop priče, kojom je diskretno označena neopozivost njegove odluke. Početak istrage povezan je sa prvim Florjanovićevim pucnjem u pticu, i ishod je već tada simbolički nijansirano obilježen neminovnošću. Ukras na dršci

28 Isto, 298. Podvukao V. B.

29 Isto, 299.

30 Isto, 281. Podvukao V. B. Jedan deskriptivni intermeco u Proljećima Ivana Galeba, koji uvodi u Ivanov „mit“ $O$ čovjeku nad kojim smrt nije imala vlast dok god se kretao, preoblikuje identičan motiv: „Brujala je nad našim glavama predvečernja zvonjava, rujna, vruća, obilata - onakva kakvu je znam i nosim u sebi iz djetinjstva. Padala je na naša pogrbljena pleća oslonjena o mlake crljenkaste zidine trijema kao topli purpurni pokrov. Izgledalo je da joj nema kraja. Kao potop. Najzad je zamukla. Krošnja brončane zuke, koja kao da nije zvuk već samo golo treptanje zraka, držala se još samo oko zvonika; kroz nju su se zalijetale sa svojim crnim cijukom sedefaste strijele lastavica. Pa je umuklo i to. Tišina je sada bila sasvim prazna.“ В. АЕсницА, Прољећа Ивана Галеба, 171-172. Podvukao V. В. 
pištolja stopio se u motivu lastavice sa zloslutnim znamenjem crne ptice, a njen drugi dolazak označava Florjanovićev neumitni kraj. Florjanovićeva smrt trivijalizovana je mjestom događanja - to je sudski zahod; a sam opis toga prizora uvodi u aspekt Desničine književne tanatologije vezan za proces umiranja:

Na pucanj priskoči Raše a za njim dotrča i Šarić iz prizemlja. Florjanović je ležao u lokvici krvi. Užurbaše se oko njega, otvoriše slavinu i stadoše ga škropiti po licu. Poče mu se pomalo vedriti u glavi. Ležeći nauznak, osjećao je kao da se strmoglavljuje u prazninu, $s$ glavom nizdol. Najprije neodređeno i daleko, pa bliže i jasnije, doprije mu do svijesti tabanje njihovih nogu, sve jače i jače, udeseterostručeno, kao neko pijano i teško kolo, a on nikako ne može da se sjeti ko su ti ljudi i što to rade... Zatim se svi zvukovi počeše opet povlačiti, postepeno blijediti i gubiti se, u nekom ugodnom zanosu, kao pred usnuće. Tabanje koraka uskladi se u ritam koji uljuljkuje a štropot vode dođe mu kao šuškanje svile - i on osjeti da se nad njim nagnula i da mu se osmjehuje njegova Zoe, u ružičastom taftu, zadihana od sreće, s nakrivljenim diademom na glavi... Upinjao se da otvori oči, ali nije nikako mogao: na vjeđe mu je legla neka čudna težina, težina bez pritiska, pamučasta a nesavladiva. Sum vode u gruboj školjki bivao je sve tanji i tanji, pa se sasvim profini, ufitilji - i najzad se prometnu u srebren mlaz talijanske česme što šikće u plavo nebo, sva u suncu... A čas zatim - sve isplinu. ${ }^{31}$

Slike prestanka vitalnih funkcija organizma i rasplinjavanja svijesti junaka Desnica uobličava sa nesvakidašnjom uvjerljivošću. Pripovijetka Pred zoru, koja uz dvije prethodno analizirane ide u najuži krug piščevih vrhunskih ostvarenja, takođe posebno obrađuje trenutak nastupanja smrti. Na samom početku Desnica uvodi jednu epizodnu junakinju Zimskog ljetovanja, koja postaje slučajnom žrtvom nasumičnog noćnog puškaranja:

Ovog je puta jedina žrtva bila gluhonijema djevojka, „mutava Sava“, koja je baš u taj čas bila izašla napolje da prepne konja u djetelini. Neobjašnjiv ubod pod plećkom, gust i topao mlaz u ustima; pod njom se posjekle noge, i dok još ne zna da li da se povinuje ili da se odupre tom porivu što je baca na koljena - a već leži izvijena nauznak na ledini: nad sobom vidi modrinu neba na kome krotko žmirka bezbroj sitnih zvijezda, glava joj šumi i misao se mrsi, nekud odlaze snage i ovladava neka slatka nemoć... Primila je i to sa onim istim zadivljenim neshvatanjem kojim je primala i sve drugo u životu: štogod bi naišlo, dočekivala je pokorno, kao jedinu mogućnost - valjda nije ni znala da se stvarima može tražiti objašnjenja i pitati za smisao i razlog. ${ }^{32}$

Oba navoda ilustruju začudnu vjerodostojnost sa kojom Desnica uobličuje prizore umiranja, u dosadašnjoj kritici najčešće vezivanu uz pojam naturalizma. Uočljivo je da narator minimum pažnje posvećuje fiziološkoj strani umiranja, već da svu koncentraciju usmjerava ka posljednjim fazama čovjekovog psihičkog postojanja. Čak i kada fokus uputi na „fizički aspekt“ smrti, Desnica se usredsređuje na njegove odjeke u svijesti umirućeg: „neobjašnjiv ubod pod plećkom“" (podvukao V. B.) ne označava izmicanje van dometa pripovjedačevih izražajnih mogućnosti, već je riječ o junakinjinoj zbunjenosti koja ni sa čim ne može da uporedi iznenadni osjećaj. Pisac, takoreći, smrt opisuje „iznutra“, i u ovakvim slučajevima prije bi se moglo govoriti o psihološkom naturalizmu, nego o naturalizmu u njegovom

31 V. Desnica, Tu, odmah pored nas, 301.

32 Isto, 303. 
uobičajenom značenju. Naročito se izdvaja momenat savladavanja čovjekove volje - on predstvalja prelomni trenutak između postojanja i nepostojanja: „na vjeđe mu je legla neka čudna težina, težina bez pritiska, pamučasta a nesavladiva“; ,još ne zna da li da se povinuje ili da se odupre tom porivu što je baca na koljena“. To je čas u kome tijelo klone i preostali tračak svijesti predstavlja posljednji eho biološkog trajanja. Takvom načinu prikazivanja smrti implicitna je „filozofija“ Desničinih pripovijedaka: smrt je bezglasno urušavanje, implozija bića bez znatnog uticaja na okruženje u kojem se događa.

U pripovijeci Pred zoru Desnica umjetnički promišlja timor mortis - čovjekov strah od smrti. Glavni lik pripovijetke - Bogdan - strijeljan je odlukom prijekog suda jer je tokom okršaja partizanskih snaga i seoske straže iz svoje kuće potajno pucao na komšiju Petraša, sa kojim je odranije imao neraščišćene račune. Iako je Petraš pripadao suprotstavljenim redovima, Bogdanova priznanja, koja dolaze nakon pokušaja da prikrije svoju umješanost, neuvjerljiva su partizanima koji su upali u selo. Kao i u Florjanoviću, završni pasus prikazuje junakove posljednje časove, stavljajući akcenat na njegov doživljaj samrtničke izbezumljenosti:

U Bogdanu sve prenaglo splasnu, skljoka se tako nisko da više iz njega ne vrisnu ni očaj ni pobuna - činilo mu se da evo kroči u smrt po treći, po četvrti put. Iz nedaleka grma ispade do po trupa krava meljući utrgnutu grančicu: zastala, uprla mirne oči i vlažnu njušku u grupu ljudi. Bogdan je spazi; iz pomirene pregorenosti laznu očajno želja za životom: osjeti silnu, neodoljivu privlačnost prema toj kravi - ujedno i zavist i nostalgiju - zaželi svom snagom da mu je uteći u nju, skriti se u mračnoj i dobroj toploti njene nutrine, i poživjeti tako, slijepo i zaštićeno, bez kraja i konca... Vojnici ga privedu k hrastu, odstupe nekoliko koraka i podignu puške. Gluha lupa srca u njemu stade da buja, buja, da prerasta van njega, da mu odjekuje bolno u ušima, zagušujući i zamagljujući sve uokolo, i zvukove, i slike, i misli. I kad grunu plotun, njemu se učini da dopire s nekog drugog svijeta, i da to ne puca u nj već u njegovu praznu košulju. ${ }^{33}$

Trenutak spoznaje neopozivosti smrti Desnica prikazuje kao jednu fazu umiranja. Zaglušujuće rastući strah dovodi Bogdana do postepene psihičke redukcije: od osjećanja zavisti prema životinji, preko krajnje inhibicije čula, do iluzije smrti momenat prije samog njenog nastupanja. Pripovjedačko uživljavanje u Bogdanovu prestravljenost prikazuje posljednju etapu svijesti čovjeka koji, ne videći apsolutno nikakvu mogućnost bijega od smrti, izlaz apsurdno traži u njoj samoj. Kada je Bogdan prvi put istinski spoznao šta mu se sprema, narator njegov unutrašnji psihološki obrt opisuje upečatljivim poređenjem: „On gotovo nagonski osjeti u sebi poriv prema istini, kao što pritiješnjena zvijer pogodi na izlaz iz zatvorenog obruča. “34 Taj obruč se pred streljačkim vodom sasvim zatvorio i njegova svijest, pritisnuta neizdrživim strahom, instinktivno otpočinje svoju dezintegraciju čas prije nego je puščano zrno faktički inicira. Pucanj „u njegovu praznu košulju“ može se uzeti kao najizrazitija metonimija poimanja neznatnosti pojedinačne smrti, kakvom je Desničine pripovijetke u piščevim najboljim stvaralačkim trenucima uobličuju. Ovoga puta takvo viđenje smrti posredovano je sviješću umirućeg subjekta, i pripovijetka predstavlja konačni izraz

33 Isto, 313-314.

34 Isto, 308. 
autorovih nastojanja da svojoj viziji pribavi umjetničku i misaonu punoću, pridružujući je najvišim dometima u toj tradiciji evropske proze. ${ }^{35}$

\section{DJETINJI DOŽIVLJAJ, KARNEVAL SMRTI I METAFIZIČKO PREDOSJEĆANJE - PROLJEĆA IVANA GALEBA}

Smrt u Proljećima Ivana Galeba predstavlja jednu od kontrapunktskih tematskih linija, upravo onako kako sam podnaslov knjige sugeriše: Igre proljeća i smrti. Fundamentalna strukturna karakteristika romana - njegova preovlađujuća homodijegetička perspektiva predodredila je autorov pristup „u suštini jedinoj temi pjesnika“ ${ }^{36}$ Dominantni naturalizam Zimskog ljetovanja i u osnovi realistički postupak u Desničinim pripovijetkama smijenjeni su poetsko-fenomenološkom esejizacijom - meditativnom analizom tanatoloških aporija glavnog junaka. Proljeća Ivana Galeba umjetnički istražuju čovjekovu neposrednu antagonizovanost sopstvenoj konačnosti, njegovo izravno misaono sučeljavanje sa neizbježnim epilogom svake egzistencije. ${ }^{37}$

Desnica je u svom kapitalnom djelu sumirao, ali i prevrednovao vlastita umjetnička promišljanja smrti. Proljeća Ivana Galeba u tom smislu predstavljaju i jednu vrstu autopoetičke ratifikacije piščevog lirskog opusa, budući da se jedino u njegovoj poeziji, kako u zbirci Slijepac na žalu, tako i u nepublikovanim pjesničkim tekstovima, mogu pronaći tragovi i temeljnije literarne razrade antropološkog i metafizičkog optimizma. ${ }^{38}$ Slika vedrog dana, kao metafora transcendencije sa ne sasvim oprečnim, ali bitno drugačijim predznakom u odnosu na pesimističko predosjećanje praznine - bešćutna, lelujava prisutnost minimalnog ostatka bića na granici ovozemaljskog postojanja i onostranosti, to su varijacije Galebovih refleksija, začetih u nekim Desničinim pjesmama. ${ }^{39}$

35 Uр. Виктор Иго, Последюи дан насмрт осуђенога, Крањево 1987.; Fjodor Mihajlovič Dostojevsкі, Idiot, Beograd 1983.

36 „Smrt je u suštini jedina tema pjesnika.“ В. АЕсницА, Прољећа Ивана Галеба, 80.

37 „Zimsko ljetovanje Vladana Desnice je posredno traženje odgovora o smislu egzistencije. (...) Prvi je roman šire postavljena slika sraza dvaju načina egzistencije: primitivne i civilizirane, a drugi, Proljeća Ivana Galeba, individualni je revolt protiv postojećeg živovanja.“ Gajo Peleš, Poetika suvremenog jugoslavenskog romana, Zagreb $1966 ., 120$.

O tome vidjeti: Vladan BAjČEta, „Slijepac na žalu. Poezija Vladana Desnice“, Vladan Desnica i Split 1920. - 1945. Zbornik radova sa znanstvenog skupa Desničini susreti 2014. (ur. Drago Roksandić i Ivana Cvijović Javorina), Zagreb 2015., 125-145; Vladan BajČETA, „Gozba u poljima. Fragmenti rekonstrukcije pjesničke zbirke Vladana Desnice u rukopisu“, Split i Vladan Desnica 1918. - 1945.: umjetničko stvaralaštvo između kulture i politike. Zbornik radova sa znanstvenog skupa Desničini susreti 2015. (ur. Drago Roksandić i Ivana Cvijović Javorina), Zagreb 2016., 459-481; Vladan BAJČETA, „Nekoliko pjesama Vladana Desnice u rukopisu“, Hrvatsko-srpski/srpsko-hrvatski interkulturalizam danas. Zbornik radovas međunarodnoga znanstvenog skupa Desničini susreti 2016. (ur. Drago Roksandić), Zagreb 2016., 259-282.

Desnica je preosmislio i nadgradio tradicionalne predstave smrti bliske takvom poimanju, uobličivši osobeno umjetničko shvatanje smrti u duhu jednog panteističkog spiritizma. Up. „Zar nije umrli kod spiritista lutalačka duša i slabi dašak, utvarna replika vidljivog oblika? U stvari, ta filozofija lišavanja, zamenjujući kvantitativne degradacije razlikama, po samoj prirodi jeste ujedno filozofija antropomorfnih ili biomorfnih analogija, jeste filozofija koja zagrobni život smatra nekom vrstom podživota, odnosno onemoćalog, prigušenog i razređenog života. Takav je podzemni svet u Odiseji, oslabljena kopija zemaljskog života, takav je taj podzemni pod-svet u kom je utvarni Ahil pandan ovozemaljskom Ahilu od krvi i mesa, svet u kom je sve magluština i dim, prigušeni odjek i izbledela senka; tamo se život stvarnog sveta svodi na neprimetno brujanje, na šapat, na pijanisimo."Viktor JANkELEvič, Smrt, Beograd 2017., 97. Ta Desničina predstava rezonira i sa različitim mišljenjima u tradiciji evropske filozofije. Na primjer, saglasno joj je Lajbnicovo uvjerenje da je „nepostojanje minimalno postojanje“ (Isto, 368) ili Hajdegerovo shvatanje 
Prvo pominjanje smrti u romanu vezano je za sudbinu Galebovog oca. Priča o misterioznom nestanku mladog pomorca, zapovjednika na jedrenjaku Margarita, obojena je pučkim nagađanjima tipično romantične imaginacije. Konsekventno umjetničkoj i idejnoj koncepciji romana, glavnom junaku se od svih pretpostavki najuvjerljivijom činila jedina koja je po svojim odlikama zaobišla njihov preovlađujući karakter. Prihvatajući intimno najvjerovatnijom mogućnost da mu je otac umjesto u brodskoj pobuni ili u tajanstvenom životu u Južnoj Americi skončao na pučini od zapleta crijeva, Galeb već tada otkriva jednu stranu svoje opsesije smrću, vezanu za tjelesni i donekle trivijalni vid čovjekove propadljivosti. ${ }^{40}$ Međutim, odaljujući se od pseudoodisejskih narativa sitnograđanske mašte, Galeb ne odlazi u ekstrem banalizacije očeve smrti, pa i smrti same po sebi, već između krajnosti neprijatno očigledne biološke trošnosti organizma i slutnje višeg, paralelnog, ili ma kakvog drugog oblika egzistencije izvan fizičkog postojanja, pronalazi ishodište u jednoj individualnoj mitologiji. Otuda i dolazi zaključak o očevoj tragediji kao nekakvom ipak mitskom događaju: „I taj mal del miserere je jedna od riječi koje su onda u mojoj nutrini odjekivale, a i danas odjekuju, golemim mitskim odjekom. ${ }^{\text {" }}$

Ivan Galeb tu svoju „mitologiju“ smrti gradi na suprotstavljanju čovjekove infantilne ravnodušnosti, sa jedne, i zrele zabrinutosti pred vlastitom konačnošću, sa druge strane. Stoga on već u uvodnim poglavljima iskazuje čuđenje nad činjenicom da svekolika religioznost nije pronašla izraza jednoj takvoj viziji smrti:

Bilo je sijaset religija i filozofija koje su tvrdile da čovjek ima dušu, i da je ta duša beskrajna i besmrtna. A često mi je bivalo čudno što nikad i nigdje nije postojalo vjerovanje da dijete ima beskrajnu i besmrtnu dušu, pa da je kasnije, kad odraste, izgubi. ${ }^{42}$

Ovaj iskaz posjeduje eksplikativno jezgro Galebove tanatologije, a umjetnička uspjelost Desničinog junaka najvidljivija je upravo u načinu na koji je u romanu razvijen takav njegov odnos prema smrti. Hipersenzibilni dječak veoma rano, u predmetima i pojavama iz svog okruženja, predosjeća prazninu postojećeg svijeta:

$\mathrm{Na}$ stolu u blagovaonici stajala je, kao ukras, blistajući među ispijenim šoljicama kave i pepeljarama prepunim čikova, srebrna kutija za biskvit u obliku globusa. Na laki dodir skrivene opružnice, gornja bi polutka naglo zijevnula i podvukla se pod donju. Kad bi mi dosadili razgovori starijih i zamorila me moja zapažanja, uzeo bih se igrati tom kutijom. Nebrojeno puta uzastopce pritiskao sam opružnicu i nalazio kao neko malo čudo u tome kako se sjajna, ispupčena oblina gornje polutke odjednom preokrene i kako, mjesto nje, najedanput zijevne praznina: nabubrela punoća oblika naglo se preobrati u šupljinu, u prazan prostor, u jedan mali bezdan mraka, postojanje se odjednom prometne u nepostojanje. Nebrojeno

relacije tubitka i fiziološke smrti: „Završavanje Živoga nazvali smo skončavanje. Utoliko što i tubitak 'ima' svoju fiziološku, životu sukladnu smrt, ali ne izoliranu kao ontičku, nego suodređenu njegovom izvornom vrstom bitka, i utoliko što se pak tubitak može završiti a da ne umre zapravo." Martin HeidegGer, Bitak i vrijeme, Zagreb 1985., 281. Pisac, dakle, misaono uporište ima u različitim filozofskim pretečama, što je od značaja jer ističe činjenicu da je originalnost umjetničke forme njegovog djela prvo što ga vrijednosno obilježava u kontekstu tradicije na koju se prirodno nadovezuje.

40 Ivan Galeb se, prema prirodi okolnosti, često osvrće na proces bolesničkog umiranja, naročito u njegovoj nemilosrdnoj nasumičnosti koja neumoljivo zatiče i djecu. Uр. В. АЕсницА, Прољећа Ивана Галеба, 54-56; 56-58; 91-93.

41 Isto, 25-26.

42 Isto, 53. 
puta, velim, ponavljao sam tu igru, nebrojeno se puta naslađivao i draškao tim spremnim, reskim zijevanjem jedne male, automatske smrti. Sklapao sam oči da bih na tankoj kožici vjeđa osjetio te male zapahe ništavila. ${ }^{43}$

Pisac dosljedno uobličuje Galebovo apokaliptičko poimanje ljudske smrti, zasnovano na pretpostavci o mikro-makrokosmičkoj homologiji. Svaka smrt je, kako će biti zapisano na drugom mjestu, ,jedan mali kataklizam“. ${ }^{44}$ Galebova percepcija iznova se zadržava na onim fenomenima koji u njegovoj svijesti potvrđuju tu ontičku podudarnost: u slučaju igre sa srebrnom kutijom za biskvit na isti način kao i u nekadašnjoj „igri miša“. ${ }^{5}$ Budući da Galeb ishod svoje igre naziva „automatskom smrću“, globusni oblik predmeta njegove fascinacije nedvosmisleno sugeriše ideju o pojedinačnoj smrti kao katastrofi opštih razmjera. Činjenica da i u ovom motivu dječja igra uzrasta do metafore demijurškog ludizma (kao i u igri miša) vodi shvatanju da Galeb intenzivno sluti fatalnu nezainteresovanost ma kakve onostrane instance za čovjekov život, odnosno za njegovu smrt. Takvoj metafizici Desnica je dao umjetnički izraz koji u sebi spaja čovjekovu prigušenu jezu apsolutne prepuštenosti volji slučaja sa vedrinom dječje zanesenosti u igri.

To paradoksalno viđenje smrti produkuje i Galebov komički pristup dominantnoj temi romana, ispoljen na jezičkom planu. ${ }^{46}$ Oduzimajući prvobitno prihvatljiv iskupljujući karakter završnici života („Smrt je ono što stvarima daje posvetu“), ${ }^{47}$ Galeb insistira na promašenosti individualnih napora da se izborom smrti pribavi izvjesno iskupljenje. Patetici herojske žrtve on suprotstavlja pasivno kliničko odumiranje:

General umire. Nastojim da ga žalim. Trudim se da saosjećam s njim. Na koncu, to mi je i dug samrtničke solidarnosti!... Jest, moj tužni generale! Ovo nije herojska smrt, smrt u švipsu slave, smrt kao činjenje. Ovo je privatna, pasivna smrt, smrt kao podnošenje. Smrt nauznačke. "Ja umirem", "Ja dajem život!", "Ja ću poginuti“! Dakako, tu sam ja onaj koji nešto čini, tu sam ja glavno lice, gospodar situacije! Ne, dragi gospodine! Ovdje se ne umire tako! Nećeš ništa ti, nego će nešto tebe. Nećeš ti nišsta dati, nego će ti nešto biti oduzeto! Nećeš ti poginuti, nego ćeš naprosto biti poginut!... ${ }^{48}$

Subjekatsko-objekatska inverzija u rečenici „Nećeš ništa $t i$, nego će nešto tebe intenzivira se, u zaključnom iskazu, do svojevrsnog sintaksičkog apsurda, kao izraza piščevog nastojanja da čovjekovoj bezuslovnoj podređenosti smrti pronađe odgovarajući pandan u stilskoj ravni. Komička učinkovitost ovakvoga obrta počiva na implicitnoj dekonstrukciji jezičke logike, koja „podsvjesno“ u sebi nosi upisanu težnju za aktivnim učešćem u činu ultimativne negacije ukupne čovjekove volje: „Nećeš ti poginuti, nego ćeš naprosto biti poginut.“

43 Isto, 46.

44 Isto, 80.

45 „To malo stakalce u djetinjim rukama i jedna zarobljena zraka božjeg sunca bili su kadri da djetetu dadu iluziju da je i samo postalo jedan mali gospod bog. Besprostoran i posvudašan; i, onako pritajen iza žaluzija, nekako ugodno odsutan iz svijeta i zbivanja, a opet ne sasvim bez uvida u njih, ne sasvim bez saznanja o njima." Isto, 23-24.

46 Na postojanje ironijsko-parodijske dimenzije u tretiranju teme smrti već je skrenuta određena pаžnја: Јован АЕ $и$ Ћ, „Чежња за бесмртношћу и негативна утопија (О једној тематској минији у роману Прољећа Ивана Галеба Вцадана Аеснице)“, Книжевно дело Владана Аеснице, 35-50.

47 В. АЕсницА, Прољећа Ивана Галеба, 80.

48 Isto, 234-235. 
Stihijsko umiranje u Zimskom ljetovanju, kako je već predočeno, posredovano je neutralnom deskripcijom koju ne prate neposredne naratorske refleksije inače personalizovanog i zainteresovanog pripovjedača. Ivan Galeb će i povodom takvih, katastrofičkih, kolektivnih stradanja, iznijeti karakteristično mišljenje:

Tek u izuzetnim vremenima, u epohama općih poremećaja, revolucija, kataklizama, život zna da odstupi od linije i da upadne u stilske nedosljednosti. Tad ljudske sudbine poprimaju nevjerovatne tokove, a ljudski životi završavaju čudnovatim, nezamislivim završecima. To su kao neka pokladna doba čovječanstva. Svijet izgleda kao neki fantastični vašar, kao neki pijani tête masquée, u kome svak nosi na glavi jednu neodgovarajuću, apsurdnu smrt kao jednu ludu karnevalsku kapu. ${ }^{49}$

Ivan Galeb je ovim zaključkom u svoju fenomenologiju smrti uveo novu perspektivu, budući da su njegova promišljanja posvećena prevashodno njenim suštinskim određenjima, izvan odgonetanja fatumskih putanja pojedinačnih, kao i zbirnih umiranja. Upadljivo je poređenje kojim se Galeb služi: epiteti pokladni, vašarski, karnevalski upućuju na temeljna obilježja ozbiljno-smiješne, karnevalske koncepije umjetnosti. Otuda se može pretpostaviti da je Desnica na izvjestan način eksplicirao pojedine ideje koje su u nekim njegovim ranijim djelima, osobito u Zimskom ljetovanju, bile tek u jednoj mjeri nagoviještene i kritički prepoznate.

Ishod svojih, na različite načine razrješavanih tanatoloških nedoumica, Ivan Galeb sažima u završnim poglavljima romana. Posljednja operacija, koja iznova uzrokuje prelazak iz budnog stanja u obamrlost, dovela je do graničnih okolnosti u kojima cjelokupno Galebovo iskustvo dospjeva do tačke svoje esencijalizacije. ${ }^{50} \mathrm{U}$ jednoj poetski inventivnoj sintagmi sabira se njegovo završno predosjećanje, pa djelimično i iskustvo zagrobne egzistencije:

Misao se mrsi. Na mahove oko mene zjape bezdane bijele praznine kroz koje propadam. Pa prestaje i to. Bijela tišina bez vremena. Sedefasti odsjev za vjeđama. Vječnost. ${ }^{51}$

To su završne rečenice LXXII, pretposljednjeg poglavlja djela, svojevrsnog romanesknog krešenda Galebove postnarkotičke levitacije između postojanja i ništavila. U tome sintagmatskom spoju, obilježenom sublimnim umjetničkim osjećanjem jezika, koncentrisana je ona epifanijska energija književnog izraza koja semantički ozračuje sve ostale, naročito tematski umrežene koordinate. Da bi se potpunije razumio epilog Galebovih igara proljeća i smrti, potrebno je sa te tačke uputiti pogled ka ključnom mjestu njenog saoznačavanja:

Za školjku, zajedno s njom umire nebosklon njezine sedefne kore. Za marvinče, s njim umiru samo jasle; jasle i rudo. Do Kolumba, s čovjekom su umirala tri kontinenta; poslije Kolumba četiri, a još kasnije pet. A s ponekim umiru čitave galaksije. ${ }^{52}$

Mada Desničin duhoviti katalog eksplicira da sve što je iskustveno, čulno i racionalno spoznato, bez izuzetka nestaje sa smrću, ipak je u njegovom razrješenju poetski nagovije-

\footnotetext{
Isto, 260.

50 Istaknuto je da se smrt kod Desnice „pojavljuje kao izuzetna i nezamenljiva saznajna pozicija“. Араган СтојАновит, „Јас живота и јас смрти“, u: ВАадан АЕсницА, Прољећа Ивана Галеба, Београд 1982., 430.

51 В. АЕсницА, Прољећа Ивана Галеба, 340. Podvukao V. В.

52 Isto, 80. Podvukao V. B.
} 
štena mogućnost transcendentnog opstojanja jednog, svjetlosnog sloja bića, lišenog onog što je tokom života opaženo i doživljeno. Prelivanje, neodređenost boje sedefa, poslužili su Desnici da pruži odgovarajući izraz Galebovoj konačnoj spoznaji. Desnica krajnju mogućnost izrecivosti njegove metafizičke slutnje pronalazi u opalescentnoj kolebljivosti sedefne materije. Veličanstvenost Galebove vizije svoju najvišu tačku time pronalazi u onome sloju iskaza koji fenomenologija književnosti imenuje mjestom neodređenosti: iza spuštenih vjeđa, kao iza sklopljene školjke, čitalačka imaginacija otkriva biser u simboličkoj dvoznačnosti, koja podrazumijeva njegovu dragocjenost i trajnost.

\section{NeMOguĆNOST NAPUŠTANJA EgZISTENCIJE I POVRATAK SMRTNOSTI - LJESTVE JAKOVLJEVE I PRONALAZAK ATHANATIKA}

U svojoj jedinoj objavljenoj drami Ljestve Jakovljeve $e^{53}$ Desnica se umjetnički intenzivnije koncentrisao na određene etičke probleme, kao što je to činio i u nekim drugim svojim djelima, naročito u pripovijetkama Pravda, Formalista, Bog sve vidi, ili Susjedi. ${ }^{54}$ Dijalozi esejističke iscrpnosti u prvom činu drame, vođeni između prijatelja Jakova Pećine i Petra Orljaka, tematizuju moralnu kredibilnost izvjesnih intelektualnih načela i građanskog ophođenja pod okolnostima nacističke okupacije, u, kako je u zaglavlju istaknuto, „nekoj evropskoj zemlji“. 55 Tu se, naime, postavljaju pitanja smisla pobune, odnosno držanja linije manjeg otpora pred konkretnim istorijskim i ideološkim izazovima. ${ }^{56}$ Opsežno teoretizujući svoj svjesno oportunistički stav, koji je u stvari vješta racionalizacija suštinskog kukavičluka, Jakov Pećina je, nakon sve opresivnijih mjera vlasti nad njegovim bližnjima, primoran da zatraži pomoć od druga iz djetinjstva Jozefa Hubera, sada šturmfirera u svom zavičaju. Tokom raspleta - koji dolazi sa Jakovljevom oniričkom vizijom u drugom činu,

53 Osim Ljestava Jakovljevih, Desničino življe zanimanje za dramsko književno stvaranje svjedoči nedovršeni rukopis pronađen u piščevoj ostavštini pod naslovom Gadni mali gnom, od kojeg su ispisana dva od tri predviđena čina. Interesantna je činjenica da se i taj dramski tekst bavi istom istorijskom epohom kao i Ljestve Jakovljeve. O tome opširnije vidjeti u: Dušan Marinković, „Nove spoznaje o Vladanu Desnici“, Desničini susreti 2005. - 2008. Zbornik radova (ur. Drago Roksandić i Ivana Cvijović Javorina), Zagreb 2010., 251-252.

54 Up. „U Proljećima Ivana Galeba i u većem dijelu novelistike Desnica je stavio u središte svojih analitičkih razmatranja ljudsku jedinku izoliranu od pripadajućeg društvenog konteksta. Njega je zanimao čovjek po sebi, oljušten od utjecaja ideologije, religije, politike. Ni odnos Ja-drugi ne postavlja se u tim djelima kao problem: pitanje ljudske 'samoodgovornosti' ostaje izvan žarišta Desničina interesa. Desničin je čovjek potpuno slobodan, bez definiranih moralnih obveza, upućen jedino na intelektualističko seciranje sama sebe. Posljedica je takva opredjeljenja bila ta da je jedan značajan krug prije svega etičkih pitanja ostao zaobiđen." Krešimir Nemec, Vladan Desnica, Zagreb 1988. 109.

55 Vladan Desnica, Zimsko ljetovanje. Pjesme. Ljestve Jakovljeve (= Sabrana djela Vladana Desnice, knj. I), Zagreb 1974., 269. Up. „Drama Ljestve Jakovljeve nastala je 1961. i svojom se radnjom vezuje za 'neku europsku zemlju pod okupacijom' (kako autor Desnica navodi u uvodu svoje drame), a zapravo uz prostor grada Zagreba početkom Drugoga svjetskog rata.“ Helena Peričić, „Jezik ideologije i ideologija jezika u Desničinoj drami Ljestve Jakovljeve“, Desničini susreti 2010. Zbornik radova (ur. Drago Roksandić i Ivana Cvijović Javorina), Zagreb 2011., 50.

56 Up. „U Ljestvama Jakovljevim ljudska je autarkičnost podvrgnuta žestokoj kritici. Drama počiva na svojevrsnoj moralnoj kazuistici: konformistički kompromis, neangažiranje u presudnom trenutku, neodgovornost prema bližnjima i davanje prednosti osobnim interesima - sve to završava moralnom katastrofom. “Jadranka Brnčić, „Problem etičkog angažmana u Desničinim Ljestvama Jakovljevim“, Intelektualci i rat 1939. - 1947. Zbornik radova s medunarodnog skupa Desničini susreti 2012. (ur. Drago Roksandić i Ivana Cvijović Javorina), sv. 1, Zagreb 2013., 48. 
a čija se prava priroda otkriva tek u posljednjoj sceni (čitaocu / gledaocu Jakovljev san predočen je kao razvoj situacije), u dijaloški prostor ulazi i tema smrti, tretirana na način bitno drugačiji u odnosu na ostale Desničine književne tekstove. Razgovor između Jakova i njegove bivše ljubavnice Vere središnje je mjesto piščevih novih tanatoloških propitivanja:

JAKOV: Čekaj!... Ostani uza me još časak!... Tako sam neizrecivo sam!... Kaži, što je tamo? Mi smo ovdje tako željni nekog otkupljujućeg saznanja!... Je li tamo odmor, zaborav, san? Bezbolnost i šutnja?... (Hvatajući je za oba zapešća.) Reci mi, Vera: kakvu poruku donosišs? Što je zapravo smrt? Kako izgleda nepostojanje? Nikako ne uspijevam da to sebi predočim!...

VERA: Moram da te razočaram, prijatelju moj! Grdno su se prevarili u računu oni koji su sav život sračunali na to konačno ništa.

JAKOV (bolno pogođen): Zar dakle nema te tačke gdje prestaje ova nesnosna podvojenost bića, gdje se najzad smiruje vječita dijalektika nadvagivanja tanjirâ na tezulji? Zar ni u samom krilu smrti ne prestaje jeza bitisanja, strah od smrti, strah od straha?...

VERA: Ne tješi se obećanim rajem ništavila! Jedina poruka koja može da se donese, glasi: sve je postojanje. Samo ništa ne postoji. Ništa je ljudski izmišljaj - jedini ljudski izmišljaj: sve što su ljudi, u tami gluhih tisućljeća, uspjeli da doista izmisle - to je ništa!... U tome i jest strahota, mili moj!... Svijet je robijaškim lancem prikovan za postojanje - Mazepa na hatu postojanja što juri ko zna kamo i ko zna zašto!...

JAKOV (jekne): O, grozne kazne!... Ni pakao gore ne bi izmislio... (Ostaje utučen, s licem među dlanovima. $)^{57}$

Desničino umjetničko shvatanje smrti - od Zimskog ljetovanja, gdje je ta tema prikazana u ozbiljno-smiješnom registru, preko pripovijedaka, koje umiranje dominantno predstavljaju kao tragični trenutak ispražnjen od svoje suštine, do Proljeća Ivana Galeba, u kojima je smrt na kraju viđena kao put u jednu ambivalentnu vječnost - zaokružuje se Ljestvama Jakovljevim kroz krajnje pesimističku viziju nemogućnosti napuštanja egzistencije. Desnica je sada uobličio sliku smrti u polaznom smislu podudarnu pojedinim njegovim pjesmama, ali prema suštinskim karakteristikama posve opozitnu tim poetskim refleksijama. Riječ je o horacijevskom non omnis moriar, lirski preformulisanom u dva potencijalna vida redukovanosti bića. ${ }^{58}$ Naime, dok je u Desničinoj poeziji smrt prizivana „da poštedi samu jednu zraku svijesti“ nosti vječnog trajanja u jednoj opskurnoj postegzistenciji.

Ništavilo je sada prikazano kao nedohvatni izlaz iz opšte torture straha i satiranja, koja kroz istoriju iznova premašuje spoznate granice čovjekove infernalne prirode. Dati navod predstavlja zgušnjavanje piščeve psihologije apsurdnog bijega od nasilne smrti u samu smrt, razvijene u pripovijeci Pred zoru. Stoga je ova „drama intelektualca“, barem u toj zamisli, umjetnički uspjela predstava nedostatnosti razumskog napora da se smrt pojmi u njenoj suštini. Ujedno, tu se nalazi zaključak piscu očevidno intrigantne ideje da okolnosti umiranja mogu odrediti njegov metafizički ishod. Čežnja Ivana Galeba za smrću „u suncu i

\footnotetext{
57 V. Desnica, Zimsko ljetovanje. Pjesme. Ljestve Jakovljeve, 320-321.

58 U pitanju su pjesme Slijepi aed, Molitva razočaranog Isusa, Dobrostiva smrt i Non omnis. Up. V. DesnicA, Slijepac na žalu, 7, 41, 52 i 57.

59 V. Desnica, Slijepac na žalu, 52.
} 
jasu“ i njegov vapaj „umrijeti u jedrini dana"60 mjesta su kristalizacije takvog umjetničkog viđenja sveopšte egzistencijalne izvjesnosti. ${ }^{61}$

Desničin nedovršeni roman Pronalazak Athanatika radikalizuje zaokret u tematizaciji smrti započet dramom Ljestve Jakovljeve. Riječ je o umjetničkom pokušaju da se smrt sagleda u svijetlu graničnih trenutaka moderne civilizacije, ovoga puta kao pokretač, a ne kao posljedica totalitarnih koncepata epohe. Serum besmrtnosti koji bi odredio konačni kriterijum društvenog raslojavanja čovječanstva poslužio je piscu kao motiv inspirativan za satiričnu obradu. Haos nastao otkrićem athanatika doveo je do ultimativnog paradoksa humaniteta - izbora između potencijalne besmrtnosti i opstanka same zajednice. Razvijajući sliku društva ,izliječenog“ od smrti, Desnica je u takvoj antiutopijskoj mogućnosti na izvjestan način dovršio tanatološki

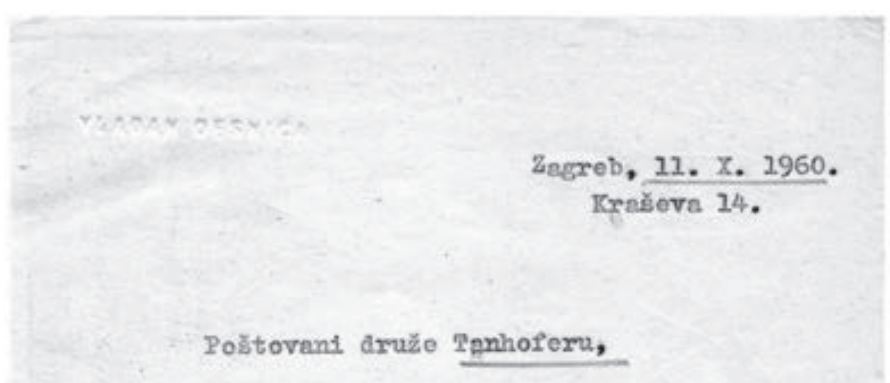

Telent "Ijestava" noreo sam da deden sa nokekav jubilernt aborntle kogi će 1z1ó1 poǒetron jenuara, u snclicu proslave, a sndržavet to soden

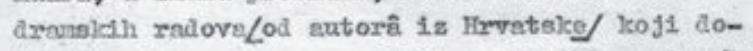
Eั1v1 javaju proul joru u jubilarnoj 1961 godint/Bo.

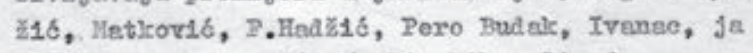
- sedmos se no ajob́an/. B10 hih volio da sell nogeo sečlenti pronif jeru, ali eto 1spalo jo talco. $\mathrm{U}$ tolcatu ses Ircsiv, IROC̆KU 1mijenio u VERU, Vi RoČxग, s "Zap1se na xubu stvernost1" $u$ "Zap1se na ivta1 atvomosti, 1 1zbscio one dvije atren1ce - scenu budjenja ne leoneu I. đ̀ine. Drugo je sve ostalo kelco jest. Tollko da mate. Alco Ven padno ne un ds b1 јоษ̆ nešto telcvo trobalo 1 . mijentti doif je etvax $u$ štanpi, jav1te ni.

Kelco ste V1? Ind ćete a Beogred? Nko nunjexnvate preleinuti put u Zagrebu, javite mi kertom pa da se enetenoso.

Srdac̆no Ves pozdravijou Vaă

Sl. 1. Pismo Vladana Desnice Tomislavu Tanhoferu o Ljestvama Jakovljevim spektar svoje literature. „Jedina tema pjesnika“ pronašla je, dakle, u „lirskom“ modelu Desničinog rada, umjetničke odjeke metafizičkog optimizma, dok je u epskim i dramskim djelima više na snazi misao obilježena antropološkim pesimizmom. Zimsko ljetovanje, pripovijetke, Ljestve Jakovljeve i Pronalazak Athanatika, za razliku od Slijepca na žalu i Pro-

60 В. АЕСницА, Прољећа Ивана Галеба, 78.

61 Tu ideju Desnica je autoironizovao u pripovijeci Proljeće u Badrovcu kroz naratorski komentar posljednjeg pokušaja junákâ da umiruću kravu podignu na noge: „Bolje da umre ovde, ako već mora! Neka ponese sobom, u ušima i očima taj meket jaganjaca i to blistavilo livade, kao što ustrijeljen zec ponese u zubićima još svježu vlatku utrgnute trave! Neka ponese puna čula te svjetlosti i tog svježeg proljetnog mirisa na onaj kravlji drugi svijet (kojega, znam, nema, kao što nema ni našeg ljudskog, ali koji ipak, onim neuništivo djetinjskim dijelom mog bića koji zaklanjam dlanovima da ga vjetri ne ugase, volim zamišljati da postoji)!“Vladan Desnica, Proljeće u Badrovcu, Beograd 1955., 120 . 
ljeća Ivana Galeba, smrt prikazuju kao metafizički nepovoljan epilog egzistencije. Stoga se za Desničino poimanje smrti, uprkos ponuđenim analogijama, može zaključiti da je u obzoru evropske književnosti krajnje apartno, budući da ga određuje kontekst u kojem se opisivana smrt događa, i da takvo shvatanje prati konsekventna distinkcija u pogledu književne genologije.

\section{ZAKLJUČAK}

Desničina književna tanatologija predstavlja izrazito kompleksnu umjetničku viziju smrti. Tražiti u toj složenosti piščev konačni odgovor na temu koju je iznova crpio predstavljalo bi metodološku pogrešku: upravo u toj polifoniji umiranja, koja se ispoljava u pojedinačnim i kolektivnim stradanjima, egzekucijama i samoubistvima, skrajnutim bolničkim propadanjima i tihim sobnim dotrajavanjima, trivijalnim i tragičnim skončavanjima, Desnica je, naročito u Zimskom ljetovanju i pripovijetkama, težio prikazivanju raspona mogućnosti u kojima se smrt neprekidno manifestuje. Njegov najviši stvaralački domašaj, roman Proljeća Ivana Galeba, odveo ga je u tom nastojanju ka sintezi svojih razmišljanja, odakle je piščeva stvaralačka putanja skrenula u začudnu metafiziku njegove jedine drame i, naročito, antiutopijsku fantazmagoričnost nedovršenog romana Pronalazak Athanatika. Sve to govori da Desničin opus nije nekakva književno zaodjenuta proklamacija određenog pogleda na svijet, odnosno na smisao smrti, koja je u njemu sveprisutna, već prevashodno artističko savladavanje svih, pa i tih sadržaja, kakvi su se u određenim okolnostima i stvaralačkim fazama piscu nametali. Njegovo umjetničko viđenje smrti u Galebovom sedefastom odsjevu za vjeđđama primiče ga, po vrsti metafizičke slutnje i jezičkoj snazi njenoga uobličenja, Desničinom najvećem prethodniku, piscu koji ga je značajno odredio - Petru II Petroviću Njegošu. Odatle proizlazi, a u ovom radu je nizom nedvosmislenih primjera još jednom, na datom tematskom kompleksu potkrijepljeno, da Desničino mjesto u nacionalnoj i svjetskoj literaturi ne samo dvadesetog vijeka daleko nadilazi njegov aktuelni status.

\section{$\cos$}

\section{Izvori i literatura}

\section{Izvori}

ВАаАан АесницА, Есеји, иланщи, погледи, БеограА - Приштина 1993.

Vladan Desnica, Olupine na suncu, Zagreb 1952.

ВАадан АесницА, Прољећа Ивана Галеба, БеограА 1990.

Vladan Desnica, Proljeće u Badrovcu, Beograd 1955.

Vladan Desnica, Slijepac na žalu, Zagreb 1956.

Vladan Desnica, Tu, odmah pored nas, Novi Sad 1956.

Vladan Desnica, Zimsko ljetovanje, Sarajevo 1966.

Vladan Desnica, Zimsko ljetovanje. Pjesme. Ljestve Jakovljeve (= Sabrana djela Vladana Desnice, knj. I), Zagreb 1974. 


\section{Literatura}

Vladan BAJČEta, „Gozba u poljima. Fragmenti rekonstrukcije pjesničke zbirke Vladana Desnice u rukopisu“, Split i Vladan Desnica 1918. - 1945.: umjetničko stvaralaštvo između kulture i politike. Zbornik radova sa znanstvenog skupa Desničini susreti 2015. (ur. Drago Roksandić i Ivana Cvijović Javorina), Zagreb 2016., 459-481.

Vladan BAJČETA, „Nekoliko pjesama Vladana Desnice u rukopisu“, Hrvatsko-srpski / srpsko-hrvatski interkulturalizam danas. Zbornik radova s međunarodnoga znanstvenog skupa Desničini susreti 2016. (ur. Drago Roksandić), Zagreb 2016., 259-282.

Vladan BAjČEta, „Slijepac na žalu. Poezija Vladana Desnice“, Vladan Desnica i Split 1920. -1945. Zbornik radova sa znanstvenog skupa Desničini susreti 2014. (ur. Drago Roksandić i Ivana Cvijović Javorina), Zagreb 2015., 125-145.

Тихомир БрАјовић, „Облик празнине. Културни идентитети и њихова наличја у Зимском ьетовану Вцадана Аеснице“, Кюижевно дело Владана Аеснице. Зборник радова поводом 100-годишғищерођења (ur. Јован Радумовић, Аушан Иванић), Београд 2007., 87-117.

Jadranka BRNČIĆ, „Problem etičkog angažmana u Desničinim Ljestvama Jakovljevim“, Intelektualci i rat 1939. - 1947. Zbornik radova s medunarodnog skupa Desničini susreti 2012. (ur. Drago Roksandić i Ivana Cvijović Javorina), sv. 1, Zagreb 2013., 41-51.

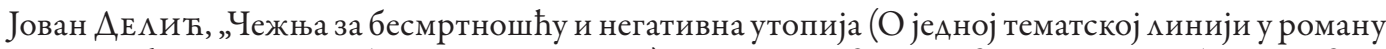
Прољећа Ивана Галеба Владана Аеснице“", Книжевно дело Владана Аеснич. Зборник радова поводом 100-годишғище рођења (ur. Јован Радуловић, Аушан Иванић), Београд 2007., 35-50.

Fjodor Mihajlovič Dostojevski, Idiot, Beograd 1983.

Davor Dukić, „Nekoliko imagoloških opaski o Zimskom ljetovanju i Desničinim susretima“, Desničini susreti 2005. - 2008. Zbornik radova (ur. Drago Roksandić i Ivana Cvijović Javorina), Zagreb 2010., 149-156.

Петар ЏАџић, Повлашћени простори Милоша Црғанског, Београд 1993.

Martin Heidegger, Bitak i vrijeme, Zagreb 1985.

Виктор Иго, Последюи дан на смрт осуђенога, Крањево 1987.

Viktor JANKelevič, Smrt, Beograd 2017.

Zoran Kravar, „Zimsko ljetovanje Vladana Desnice pod ideološkokritičkim lećama“, Desničini susreti 2010. Zbornik radova (ur. Drago Roksandić i Ivana Cvijović Javorina), Zagreb 2011., 9-17.

Dušan Marinković, „Nove spoznaje o Vladanu Desnici“, Desničini susreti 2005. - 2008. Zbornik radova (ur. Drago Roksandić i Ivana Cvijović Javorina), Zagreb 2010., 241-254.

Krešimir Nemec, Vladan Desnica, Zagreb 1988.

Vlatko Pavletić, Analiza bez koje se ne može, Zagreb 1961.

Gajo Peleš, Poetika suvremenog jugoslavenskog romana, Zagreb 1966.

Helena Peričić, „Jezik ideologije i ideologija jezika u Desničinoj drami Ljestve Jakovljeve“, Desničini susreti 2010. Zbornik radova (ur. Drago Roksandić i Ivana Cvijović Javorina), Zagreb 2011., 49-61.

Араган СтојАновит, „Јас живота и јас смрти“, u: Владан Аесница, Прољећа Ивана Галеба, Београд 1982., 425-450.

Luca VAGLIo, „Vidovi policentrizma i problematičnosti u romanu Zimsko ljetovanje Vladana Desnice“, Desničini susreti 2010. Zbornik radova (ur. Drago Roksandić i Ivana Cvijović Javorina), Zagreb 2011., 101-108. 


\section{$\cos$}

\section{THE PEARLESCENT REFLECTION OF ETERNITY. The thanatological aspects of the work of Vladan Desnica}

It is impossible reduce the vision of death in the work of Vladan Desnica to a single critical determination. Desnica's literary thanatology is immensely varied in the ways it depicts and conceives human existential finality. In the span between metaphysical optimism on the one hand and pessimism on the other, Desnica's work is the most encompassing. His range in that aspect becomes evident in the parallel analysis of the Desnica's short stories, lyrical and reflexive fiction, as well as his play. In Desnica's narrative fiction and Zimsko ljetovanje (Summer vacation in winter), a bleaker vision of human transience is established, one which often veers towards the grotesque. In his poetry, especially the poems found among his manuscripts, there is a clear vitalist charge in the way man faces death, stoically, and at peace with the cyclic nature of life. Desnica's central work Proljeca Ivana Galeba (The Springs of Ivan Galeb), as his crowning achievement, unites and in a way reconciles the extremes of the effort to overcome this basic anthropological fear. The paper examines the relationships between Desnica's thanatological variations in the different modes of his literary expression, while attempting to answer the question of how to understand the image of death in the work of a writer who has tackled it in countless different ways.

Key words: death, dying, funeral, eternity, pearlescent/mother-of-pearl, the apocalyptic, non omnis moriar 